\title{
Research on Problems and Countermeasures of Network Bank in China
}

\author{
$\mathrm{Yu}$ Han \\ School of Finance, Guizhou University of Finance and Economics, \\ Guiyang 550025, China \\ 51forest@sina.com
}

\begin{abstract}
Recent years network banks develop rapidly in china, the outlook is very optimistic, but so far application is not enough widespread, the service is not perfect, there are still many aspects need to be strengthened and improved. Based on this, the paper focuses on reviewing the development characteristics of China's network banks and problems existing in the network banks development, and then proposes countermeasures on the drawbacks to promote the healthy development of China's network banks.
\end{abstract}

Keywords: network bank, characteristic, problem, countermeasure.

\section{Introduction}

Network bank is also known as online bank, e-bank, internet bank, refers to bank uses the internet technology, via the internet to provide account opening, account cancelling, query, reconciliation, internal bank transferring, interbank transferring, credit, online securities, investment wealth management and other online financial service to customers. Here the online financial services refer to the substantial financial services; in addition to the traditional commercial bank businesses you can also make online payment and settlement. Those traditional banks that have their own websites, but only carry out image publicity and business introduction, at most, can only be considered "bank in the internet", instead of "network bank." Network bank currently has two forms: one is the new network banks develop entirely dependent internet, all business transactions of these banks rely on the internet; another is developed on the basis of existing commercial banks, use the internet for the banks services business, open up a new e-service window, namely called plug electronic banking system of traditional business [1]. At present, the network banking business offered in our country are all belong to the latter. From the view of network bank's operation, they have the following characteristics: Business intelligence, virtual. Network banks have no buildings, no address, only the web site, their branches are virtualization cyberspace brought by internet and terminals, mainly through intellectual capital, customers do not have the help of bank staff, can own in a short time complete account inquiry, funds transfer, cash deposit and other banking business, can 
self-service access network bank high-quality, fast, accurate and convenient service. (2) Services personalization. Internet provides interactive communication channels for banking services customers can put forward specific service requirements when accessing network bank sites, there are one to one financial solutions between network banking and customers that enable financial institutions in the interaction with customers to implement unique, targeted services and win customers through proactive service. (3) Financial business innovation platform. Network banks focus on using the advantage of low-cost and a wealth of information resources on the internet to provide corporate credit rating, corporate personal financial advisers, expert investment analysis and other services for financial institutions, increase the added value of information, and strengthen the information intermediary function of banks [2].

\section{Drawbacks in the Development of China's Network Banks}

1) Security Issues. This is probably a big reason that makes most people stay away; the security issue is the most important issue of network banks, because security is essential for customers, merchants, banks. Payment information of traditional payment means is transmitted on the bank's internal network, generally there are secure safety isolation measures between the internal network and external networks, and internal network security is relatively high. Online payment information is transmitted publicly on the internet, exist the hidden dangers that payment information is tampered or theft [3]. Able to provide a secure system, a good consumer interface, a good security guarantee is that everyone wants to see, until network banks can solve this problem believe that network bank can get a great development. At present the main security issues are: (1) System security risks. Although the network banks are designed with multiple layers of security systems and emerge new security technologies and solutions to protect the smooth running of virtual financial counters, but the network bank's security system is still the weakest part in network bank's services business. This risk is not only from the computer system down, disk arrays destruction and other uncertainties, but also from outside network digital attacks, as well as computer virus damage and other factors. (2) operational risk. Operational risk is the possibility of potential loss caused by significant shortcomings in system reliability, stability and security. Such risks may come from the design flaw of network bank security systems and their products or operational errors, can also result from the negligence of network bank customers, staff misuse in business, may lead to serious operational risk of network bank.

2) Social Credit Environmental Issues. In recent years, although China's market economy has been developing rapidly, but the development of social credit system is lagging behind, dishonesty phenomenon in economic activity is quite serious. In terms of constructing personal credit system China is still basically a blank, which is also the reason of the vast majority of customers take wait and see attitude for network banks. 
3) Business Concepts and Management System are Lagging Behind. The strength of traditional banks is from lower asset-liability ratio and capital credit capacity, the engaging business is mainly reflected in the assets and liabilities business. In addition, our traditional banking industry has followed static single-center multi-level management philosophy. However, the strength of network bank is mainly from the wisdom of the investment and decision-making, its business is mainly manifested in intermediate business and providing a variety of financial advice to the public. The development of network bank requires to scientific and technological innovation as the driving force, multi-center, multi-level dynamics manage the various financial services provided by banks. However, China's network bank is still substantially in the stage of moving the traditional business to process on the internet, if the stereotype and mechanisms of traditional banks are not timely convert, will bring difficulties to the development of network banks [4].

4) Legal Basis Issues. Currently in China the legislation involving in network banking is not perfect, because the network banking business is a new banking areas, to carry out its business involves in all aspects of e-commerce and the various participating parties’ interests, however, the existing laws still lag behind the development of network bank, for instance, customers' obligations, bank's responsibilities and rights between each other are still no clear legal definition, make all parties participating in network banks face certain legal risks.

5) Lack Unified Planning and Unified Standards in the Designation and Development of Network Banking System. Carrying out network banking services depends on networking bank's background clearing system. However, the network construction of China's financial industry is lack of overall planning, lack of a platform of bearing, scalability, security, uninterrupted, low manageable, result in one hand interconnectivity between domestic commercial banks is poor; On the other hand, the unity of all commercial banks in itself is not satisfactory. In addition to several new commercial banks, state-owned commercial banks have their own computer systems in each branch, hardware and software varies. Developing an online payment system for each platform in such a multi-platform system, the difficult can be imagined.

6) Lack of Personnel Adapting to the Development of Network Bank. Network bank determines the highly penetration between financial and computer networks, the amphibious personnel not only proficient in computer network communication technology but also understands the financial practices can quickly and accurately grasp the market pulse in the fierce market competition and make a positive response, network bank especially in its management layer urgently need for such talent.

\section{The Countermeasures for the Healthy Development of Our Country's Network Banks}

Through the above analysis of the many new issues facing the banking network, we can see the development of network banks upgrade the banking industry 
regulatory to a higher degree of difficulty, network banking risk supervision and control become more complex. We consider that in order to effectively control the problems posed by network bank, for a variety of risks characteristics must establish national, industry and enterprise three levels of network banking supervision system, support each other, complement each other, to achieve strongly predict control and defuse for the new issues.

1) Vigorously Promote Information Technology and Network Construction. Expand survival space of network banks, the development space of e-commerce and network bank depends on the scale level of information infrastructure, the spread extent of information terminals and the information knowledge. Therefore, should strengthen the network information infrastructure, popularity of computer and network knowledge as soon as possible. At present stage must raise awareness, enhance urgency sense, need to further promote the use of network bank achievements, make nationals through perceptual, feel the advantage of network bank development on China's information technology, automation, modernization, feel the significant role of network bank for promoting national economic development, through education, training, etc. to enhance national quality, updated financial management concepts, to develop internet services, improve the networking level of the bank system, which is the premise to promote the development of network bank, also is imperative.

2) Strengthen the Social Credit System Construction. Network bank is virtual banking services means based on internet, banks and their customers may be generated distrust. Using the same kind of planning platform, the same standard means, the same kind of technical processes, establishing a unified, efficient, objective, impartial social credit system, reducing financial credit crisis, to improve people's trust level for network bank payment methods, lay a good credit foundation for network bank development.

3) Strengthen Network Banking Marketing and Innovation Efforts. US financial industry places great emphasis on marketing, use marketing concepts to guide banking business operations, commercial banks pay attention to the market, continue to introduce personalized service. Therefore, China's commercial banks should deeply understand this point, and truly implement American business philosophy into carrying out network banking business. Online business innovation should reflect from every aspect, and reflect whether is perfect can only starts from the practice, so make online banking can offer more competitively priced financial products. Financial products marketing strategy is very different from general merchandise, the traditional financial industry marketing is "product-centric", and network products are intangible, marketing model must to be "customer service-center". With the highly development of information technology, the differences of network financial products and services provided by different financial institutions are shrinking, focus on marketing strategy, expand the brand effect will be the key to attract customers and expand business scale for network bank, constantly develop new products to meet customers' needs.

4) Accelerate the Construction of Legal System. Compared to traditional banks a lot of network bank problems are more complex, difficult to define, this situation 
has caused concern around the world, United States, Australia, Singapore and other countries have issued Electronic Transactions Act. In China, policy and regulations construction in this regard are obviously lagged behind, should intensify enact "People's Republic of China Network Banks Act", refer and learn legislative experience and recommendations of related countries, regulate the behavior of network financial participants: clarify the rights and obligations of banks and customers both sides with legal form to, trading rules, transaction contract valid or not, deal with accidents and modify the existing legal norms and rules based on technology development, also should have the corresponding legal sanctions computer crime, computer leakage, steal trade and financial secrets [5]. China needs to strengthen supervision of network banks. According to the actual situation of the network banking sector, as soon as possible establish the laws and regulations suitable for network banking operation and running, severely punish criminals that who use computers to commit a crime in the network bank system, so as to improve security protection in the legal system for the development of network banks. Network banks have no national boundaries, so it is necessary to strengthen the cooperation with international organizations and each country's financial judiciary and the competent departments in the world, to solve cross-border, cross-border financial data streams regulatory issues, to develop international treaties of jointly fight against network financial crime and regulatory networks financial industry risk responsibilities, to ensure the smooth development of the network financial industry.

5) Accelerate to Train Highly Qualified Personnel for Network Bank. Network bank determines the highly penetration between financial and computer networks, the amphibious personnel not only proficient in computer network communication technology but also understands the financial practices can quickly and accurately grasp the market pulse in the fierce market competition and make a positive response. Therefore, we must strive to introduce talent and advanced foreign intelligence, also attach great importance to strengthen the training and education of existing staff, especially operational training, strive to build complex personnel not only understands information technology but also understands the e-commerce rules and network banking operations.

6) Focus on Building Network Bank Brand. Strive to build Network bank services' brand, Chinese people always ignore brand building. Establish a comprehensive market brand strategy, currently each bank have its own network bank, financial services provided have small differences, so it is necessary to develop their core products, establish their own services' brand, establish advantage business to get more customers.

\section{Summary}

At present, China's network bank only is the online transplantation of traditional banking business, does not play electronic bank's restructuring and reengineering function for banking business, only plays the channel role of traditional banking business, the product does not get rid of the limitations of 
traditional business functions, the user interface does not reflect the characteristics of personalized service, but is the simple imitation of traditional business processing system interface. Based on this, we should vigorously promote information technology and network construction, strengthen the social credit system construction, strengthen network banking marketing and innovation efforts, accelerate the construction of legal system, and accelerate to train highly qualified personnel for network bank six aspects to effectively control the problems existing in network bank, thereby promoting better development of network bank.

\section{References}

[1] Sun Sen, Network Bank [M], Beijing: China Financial Publishing House, 2010.

[2] Wang Yanhui, Xiao Xuemei, Zhang Chengchen, Electronic Payment and Network Bank [M], Beijing: Tsinghua University Press, 2010.

[3] Xie Yuan, Risk monitoring system of network bank [J], Shanghai Finance, 2014 (05) .

[4] Ruan Yinglan, The influence of network bank on financial sector and its countermeasure analysis [J], Development research, 2008 (03) .

[5] Ren Xingli, Network bank: issues and development parallel, risks and benefits share [J], Productivity Research, 2006 (06). 